\title{
A comparative analysis of the implementation of anti-corruption legislation by anti-corruption agencies in the provinces of the Eastern and Northern Cape
}

\author{
TMAJILA, JD TAYLOR ${ }^{2}$ AND KRAGA
}

\section{Abstract}

Many countries experience various degrees of corruption. South Africa is no exception. The undeniable fact is that corruption cannot be reckoned as a mere country- or regionspecific problem; it is a far wider phenomenon. However, there has been a growing global movement to condemn corrupt practices, resulting in the removal of certain leaders from office. South Africa has formulated and promulgated legislation that is considered an international example of good practice and has established agencies for the purpose of combating corruption. The Institute for Security Studies (2007:1) proposes that anti-corruption legislation, if enforced, should equip the country's anti-corruption agencies with a tool that could effectively be utilised as a punitive instrument for offenders and a deterrent for those contemplating corrupt activities.

This article examines whether anti-corruption agencies are apolitical and capable of detecting and punishing corruption or whether they are only a response to international demands by international agreements. In this regard the United Nations Convention against Corruption, the SADC Protocol against Corruption and the African Union Convention on Preventing and Combating Corruption are discussed.

The article concludes with recommendations based on an empirical survey of anticorruption legislation and anti-corruption agencies conducted in the Eastern Cape and Northern Cape Provinces.

\section{Introduction}

South Africa, like most other countries, faces challenges in preventing and combating corrupt behaviour. According to the National Planning Commission (2011:446), South Africa suffers from high levels of corruption that undermine the rule of law and hinder development and socio-economic transformation. However, in the democratic era, steps have been taken to counter corrupt practices and put accountability mechanisms in place.

Corruption is known to have a disproportionate impact on the poor in terms of income inequalities and access to essential services and resources, and it undermines opportunities for building secure livelihoods and economic empowerment (Chêne and Hodess, 2010:3). The

1. Dr Thozama Majila is deputy director: Housing Policy Development Eastern Cape Department of Human Settlement, East London. E-mail: thoziv@gmail.com.

2. Prof John Derek Taylor is in the Department of Political and Governmental Studies Faculty of Arts, PO Box 7700, Nelson Mandela Metropolitan University, Port Elizabeth, 6031. E-mail: Derek.Taylor@nmmu.ac.za.

3. Prof Kishore Raga is a research associate at Nelson Mandela Metropolitan University, Port Elizabeth,6031.E-mail: kishore.raga@,nmmu.ac.za or Raga.kishore@gmail.com 
costs of corrupt practices fall most heavily on the poor because these costs degrade the quality and accessibility of public services (National Planning Commission, 2011:446). State systems of accountability have been disparate, thereby enabling corruption to thrive. Bassey, Ndem, Michael and Awa (2012:55) state that corruption poses a serious challenge and undermines democracy and good governance by subverting formal processes. Furthermore, corruption in public administration results in the unequal or non-provision of services to its citizens. At the level of individuals and households, there is mounting evidence of the negative effects of corruption on the health and welfare of citizens (Vian, 2013:83).

Carr and Outhwaite (2008:18) explain corruption as a "cancer" on development and declare that "there is nothing more important" than the fight against it. South Africa has followed this trend by embarking on a number of anti-corruption initiatives. Within the United Nations system, South Africa has initiated the following three initiatives: the adoption of the United Nations Convention against Transnational Organised Crime (2000); the launch of the Global Programme against Corruption (2000); and the work on the preparation of a United Nations Convention against Corruption (2002).

South Africa, through anti-corruption legislation and anti-corruption agencies also plays a prominent role in fighting corruption within the African context, such as in the New Partnership for Africa's Development (NEPAD). The emphasis in NEPAD is on good governance and the adoption of the Africa Union Convention on Preventing and Combating Corruption. Within the Southern African Development Community (SADC), the Protocol against Corruption was adopted in August 2001 and was ratified by South Africa in 2003. Corruption has been identified as an impediment to national integrity (Department of Public Service and Administration and United Nations Office on Drugs and Crime, 2003:37).

The Presidency of South Africa (2010:17) states that several measures have been put in place with the objective of combating corruption. According to Jackson, Muzondidya, Naidoo, Ndletyana and Sithole (2009:5), the government of South Africa has undertaken a number of other important anti-corruption measures. These measures include the adoption of the Public Service Anti-Corruption Strategy as the blueprint for anti-corruption campaigns in the public sector (2002), the promulgation of an anti-corruption related legislative framework (19972004), the development of investigating and prosecuting anti-corruption capacities, and attempts to develop partnerships with business and civil society.

Other significant developments identified by the International Bar Association (2012:1) include the following international agreements and conventions to which South Africa has acceded:

- The Southern African Development Community Protocol against Corruption;

- The Southern African Development Community Protocol on Combating Illicit Drugs;

- The African Union Convention on Preventing and Combating Corruption;

- The United Nations Convention against Corruption;

- The United Nations Convention against Transnational Organised Crime; and

- The Organisation for Economic Co-operation and Development Convention on Combating Bribery of Foreign Public Officials in International Business Transactions. 
This article endeavours to briefly explain the nature of corruption and the role of anticorruption agencies in South Africa. The South African Government's capacity to utilise legislative and administrative anti-corruption directives to address the question whether anticorruption agencies are apolitical and capable of detecting and punishing corruption is also expounded.

\section{Nature of corruption}

Curbing corruption has become a top priority in many countries throughout the world. Prioritising the fight against corruption has led to the enactment of anti-corruption legislation and the establishment of anti-corruption agencies in some countries. However, devising and implementing these control measures do not necessarily mean that corruption has been curbed since corruption is perceived as a complex phenomenon.

Hussmann, Tisne and Mathisen (2009:6) and Menipaz and Menipaz (2011:78) support this notion. They state that corruption is a complex phenomenon and that its character differs from country to country, depending on the prevailing social, economic and cultural conditions and, particularly, the legal context. They perceive corruption as a complex process and a multi-faceted issue that requires contextual analysis and understanding.

The literature acknowledges that corruption is an ancient, wide and pervasive problem that continues to be a factor in everyday lives around the world (Gebeye, 2012:5 and Vian, 2008:83). While the early years of anti-corruption work focused largely on personalised transactions, it is now recognised that corruption is a much broader problem, often ingrained in political systems (Hussmann et al., 2009:6). Corruption is a moral and ethical dimension which may be translated into legal provisions in various ways (Kolstad, Fritz and O'Neil, 2008:vi). However, in many countries such as India and Pakistan, there is a significant section of the population which does not regard corruption as being simply the result of poverty or disorder, but rather as being something that is appropriate or at least tolerable (Reno, 2008:404) .

Corruption itself does not belong only to the economic domain (Danon, 2010:28). According to Hussmann et al. (2009:6), an anti-corruption campaign should target the following: political and social dimensions (systemic corruption); the rule of law (control and prosecution); public and administration reforms (prevention) and extractive industries and service delivery (sector corruption). In addition, non-state actors (transparency and accountability) as well as capacity-building and organisational development (anti-corruption abilities) should also fall within the ambit of an anti-corruption campaign. Although the complexity factor is often mentioned in the corruption literature, few studies analyse its nature in detail. Devising effective and practical anti-corruption initiatives is unlikely without understanding the complexity of corruption.

Although forms of corruption vary from country to country according to the level of economic development and attitudes to it differing from one culture to another, corruption is fundamentally the same evil wherever it occurs (Saryazdi, 2012:503). To be able to understand the nature of corruption, perhaps the phenomenon itself needs to be defined and its extent, causes, forms and consequences need to be examined. Despite numerous international and regional anti-corruption conventions against corruption, as well as several international, self-regulatory anti-corruption initiatives, progress in the fight against corruption continues to be slow (World Economic Forum, 2009:12). Persson, Rothstein and Teorell (2012:7) state that while political actors often talk of accountability and integrity, this 
by itself does not seem to translate into a genuine and credible commitment to detect and penalise unethical behaviour.

In South Africa, legislation has been promulgated and agencies have been established for the purpose of combating corruption. However, corruption still seems to be concentrated among certain individuals in the country. In Table No. 1, Yaru (2010:146) shows the nature of corruption:

Table No. 1: Types, causes and consequences of corruption

\begin{tabular}{|c|c|c|c|}
\hline $\begin{array}{l}\text { Types of } \\
\text { Corruption }\end{array}$ & Causes & Forms & Consequences \\
\hline $\begin{array}{l}\text { Political } \\
\text { Corruption }\end{array}$ & $\begin{array}{l}\text { Weak electoral commission, } \\
\text { law enforcement mechanism, } \\
\text { judiciary and one-party } \\
\text { dominated state }\end{array}$ & $\begin{array}{l}\text { Inflation of voters, rigging } \\
\text { of elections } \\
\text { deprivation of and } \\
\text { from winners } \\
\text { parties }\end{array}$ & $\begin{array}{l}\text { Civil unrest, bad } \\
\text { governance, incompetent } \\
\text { rulers, bad international } \\
\text { image and electoral } \\
\text { violence }\end{array}$ \\
\hline $\begin{array}{l}\text { Economic } \\
\text { Corruption }\end{array}$ & $\begin{array}{l}\text { Weak state, poverty and wide } \\
\text { income gap between the rich } \\
\text { and the poor }\end{array}$ & $\begin{array}{l}\text { Bribing to win contracts, } \\
\text { influenced service delivery, } \\
\text { contract cutbacks, inflation } \\
\text { of government contracts } \\
\text { and non-payment of taxes } \\
\text { by highly-placed } \\
\text { businessmen }\end{array}$ & $\begin{array}{l}\text { Escalating cost of } \\
\text { governance, poor or non- } \\
\text { implementation of public } \\
\text { contracts, poor public } \\
\text { service delivery, closure } \\
\text { of public parastatals and } \\
\text { loss of public revenue } \\
\text { through tax evasion and } \\
\text { avoidance }\end{array}$ \\
\hline $\begin{array}{l}\text { Bureaucratic } \\
\text { Corruption }\end{array}$ & $\begin{array}{l}\text { Lack of national commitment, } \\
\text { weak state and complex } \\
\text { bureaucratic processes }\end{array}$ & $\begin{array}{l}\text { Bribery of public } \\
\text { officials and distortion } \\
\text { of due process/normal } \\
\text { procedure in the public } \\
\text { sectors }\end{array}$ & $\begin{array}{lr}\text { Bad policies, } & \text { non- } \\
\text { pursuance of policy } \\
\text { objectives, policy failures, } \\
\text { employment } \\
\text { incompetent } \\
\text { officials and poor service } \\
\text { delivery }\end{array}$ \\
\hline $\begin{array}{l}\text { Judicial } \\
\text { Corruption }\end{array}$ & $\begin{array}{l}\text { Poor salary scale, greed } \\
\text { and weak law enforcement } \\
\text { mechanism }\end{array}$ & $\begin{array}{l}\text { Free bail, distortion of } \\
\text { judgments, acceptance of } \\
\text { bribes by judges and delays } \\
\text { in passing judgment }\end{array}$ & $\begin{array}{l}\text { Persistent corruption, } \\
\text { private cost of corruption } \\
\text { lowered or reduced to } \\
\text { zero, civil unrest and } \\
\text { lawlessness and } \\
\text { decadence of rule of law }\end{array}$ \\
\hline Moral Corruption & $\begin{array}{l}\text { Non-taxation of property, } \\
\text { high level of poverty and wide } \\
\text { income distribution }\end{array}$ & $\begin{array}{l}\text { Demonstration of } \\
\text { individual materialistic } \\
\text { possession and exploitation } \\
\text { of masses by the few } \\
\text { powerful rich in the society }\end{array}$ & $\begin{array}{l}\text { Desperation to acquire } \\
\text { wealth, armed robbery, } \\
\text { civil disorder and } \\
\text { eventually revolution for } \\
\text { change }\end{array}$ \\
\hline
\end{tabular}

Adapted from Yaru (2010:146)

From the above, it can be inferred that corruption is a multifaceted phenomenon. This is probably the reason why those who write about corruption first attempt to define the concept before examining it. Defining the concept is appropriate since it would be difficult to analyse, measure, assess or fight corruption without first determining its essential qualities.

In the following section, the legislative framework governing anti-corruption in South Africa is discussed. 


\section{Legislative framework on corruption in South Africa}

The National Planning Commission (2011:446) states that South Africa has passed laws that provide a foundation for open, transparent and accountable government. Woods (2011) and the Gauteng Anti-Corruption Strategic Framework (2009) commend South Africa for having a relatively sophisticated and comprehensive legal framework which deals with corruption, transparency in procurement and financial management. However, the above authors also identify shortcomings when assessing the effectiveness of the legislation, while providing measures for mitigating these failures. The inadequacies detected are irregular accountability systems (National Planning Commission, 2011:446); the public sector's uneven capacity to enforce and comply with the legislation (Godi, 2007:6); and poor management (Woods, 2011:5).

South Africa provides an example of anti-corruption legislation outside Asia (for example, Singapore) which is often cited as a reference worldwide because these countries are considered to be the least corrupt (Chêne and Hodess, 2010:3). However, implementation of South Africa's anti-corruption legislation has proven to be ineffective. To this effect Hean (2010:151) remarks that having tough laws is no guarantee that there is effective enforcement. The Gauteng Anti-Corruption Strategic Framework (2009:8) states that the elements of an effective anti-corruption framework exist in South Africa, specifically in Gauteng. When assessing South Africa's investment climate, the US Department of State (2012) realised that the country has an excellent anti-corruption regulatory framework which is highlighted by the passage of the Prevention and Combating of Corrupt Activities Act 12 of 2004. However, the National Planning Commission (2011:446) revealed that the legislation has weaknesses such as: the failure of the Protected Disclosures Act 26 of 2000 to provide adequate protection to whistle-blowers; poor supply chain prescripts; complexity in the implementation of the Promotion of Access to Information Act 2 of 2000; and inefficiencies in South Africa's rule of law.

Despite applicable legislative prescriptions, South Africa continues to rank amongst the highest in terms of levels of corruption and perceptions of corruption. There are inefficiencies within and among institutions with regard to anti-corruption mandates, a lack of effective follow-up on complaints of corruption, inefficient application of disciplinary systems, underdeveloped management capacity in some areas and societal attitudes which weaken anti-corruption efforts (Gauteng Anti-Corruption Strategic Framework, 2009:8).

Regarding the effectiveness of this law-directed anti-corruption approach, Cronin (2013) proposes that there is every indication that corruption, particularly in the public sector, continues to escalate in South Africa. Cronin (2013) attributes this failure to poor management which results in weak application of laws and regulations, and the subsequent deterioration of the application of internal systems which, in turn, create opportunities for corruption.

\section{International anti-corruption legislative framework}

Chêne (2010:7) highlights applicable legislation pertaining to the following three countries: Firstly, Singapore's Prevention of Corruption Act (PCA) was enacted in 1960. The law explicitly defines corruption in terms of various forms of "gratification" and combines extensive prevention measures with severe sanctions and penalties. Secondly, Hong Kong's Prevention of Bribery Ordinance 1970 (POBO) is a comprehensive piece of legislation that covers all types of bribery, both in the public and the private sectors. Thirdly, Malaysia's 
Anti-Corruption Act 1997 stipulates offences and penalties for private and public sector corruption, including active and passive bribery, attempted corruption and abuse of office, corruption through agents and intermediaries, corruption in public procurement and electoral corruption (Chène, 2010:8).

Having reviewed anti-corruption legislation in 21 countries (inter alia: Australia, Bangladesh, Cambodia, the Cook Islands, Fiji Islands, Hong Kong, China, India, Singapore, Malaysia), Chêne (2010:7) concludes that good practice examples of anti-corruption legislation have been implemented in Singapore, Hong Kong and, to some extent, Malaysia.

Corrupt practices are consensual in nature, with both the giver and the taker motivated by mutual interests (Lian, 2008:4). Unlike general crime, the victim does not always reveal what has happened, possibly because he/she is also the offender. In corrupt offences both the giver and the receiver can be guilty parties who have the motivation to conceal and not tell the truth, which makes investigation and evidence-gathering more challenging (Hean, 2010:150). Hin (2011) emphasises that the law must define what constitutes corrupt offences and their punishment, and identify the powers of enforcement against them (Hin, 2011: 124).

It can be inferred that characteristics that make anti-corruption legislation successful are detection, investigation and prosecution of cases while punishment, prevention and enforcement aspects are imperative for effective anti-corruption laws. While having anticorruption legislation in place has proven to be the first step, there are other complementary measures that are needed such as: informed citizens; a need to foster and sustain high levels of professional and ethically imbued civil servants; and legislation that supports the transition towards a corruption-free society. The following measures such as: the freedom of information law, a whistle-blower protection law, conflict of interest laws, procurement laws and party financing laws have been implemented in the Republic of South Africa. For laws to be effective, they need to be enforceable.

\section{Elements of effective anti-corruption legislation}

The above-mentioned authors identify other characteristics such as detection, investigation and prosecution of cases, and punishment, prevention and enforcement aspects as imperative for effective anti-corruption laws. Del Mar Landette (2002:23) highlights specific anticorruption legislation that defines public standards of behaviour and their enforcement through investigation and prosecution as a requirement while Messick and Kleinfeld (2001), Mollah and Uddin (2002) and Hin (2011) emphasise the prevention of corruption.

Messick and Kleinfeld (2001:1) state that an obvious first step is to ensure that laws are in place to deter corruption. Prevention is regarded as better than cure. According to the DPSA Report (2006:22), the costs of preventing corruption are far lower than investigating it, holding disciplinary inquiries, and taking cases to court. In Singapore the principal law is the Prevention of Corruption Act which governs the primary offences of corruption and the powers of the enforcement agency (Hin, 2011: 124). The World Bank Group (2007:3) explains that anti-corruption laws work to deter corrupt actions, prosecute corruptors and resurrect a sense of justice.

However, Transparency International (2011: Online) argues that although it is widely recognised that the prevention of corruption should be at the forefront of reform efforts, 
effective detection and punishment through relevant anti-corruption laws and proceedings are equally important. Mollah and Uddin (2002:23) add that anti-corruption laws work to resurrect a sense of justice which has become a rare commodity in endemically corrupt countries, while the USAID (1999:11) promotes the application of sanctions to corrupt acts as an important step towards establishing accountability. The World Bank (2001:1) supports this notion and argues that laws that punish bribery and other forms of corruption have proliferated throughout the developing world (World Bank, 2001:1).

Messick and Kleinfeld (2001:2) identify three aspects of effective anti-corruption laws. Anticorruption laws should contain bright-line rules, be tailored to enforcement capacity, and be supported by complementary measures. The World Bank (2001: 2-3) advises that countries with weak enforcement institutions should consider including the following bright-line rules in their anti-corruption laws:

i. No government employee may receive any gift, payment, or anything of value in excess of a small sum from anyone who is not a member of that person's immediate family.

ii. No employee may hold, directly or indirectly (that is, through family or other agents), an interest in a corporation or other entity affected by that employee's decision.

iii. Every year all employees above a certain pay level must publicly disclose all assets they hold directly or indirectly.

iv. No employee may hire a relative (with a precise specification on how distant a relation must be before he or she is a relative).

v. All employees must disclose any relationship with people hired and with firms or entities to which they award a contact or concession. (Since in many countries the pool of talented workers and qualified firms is small, this rule leaves decisions about corruption to public opinion).

Those who formulate anti-corruption legislation need to ensure clarity and non-ambiguity of the law, that it is simple to apply, and that it demands little or no judgment in determining its applicability (Messick and Kleinfeld, 2001:2). Laws written this way are said to contain bright-line rules and are contrasted with those containing standards that are open to interpretation by enforcement agencies (Kaplow, 1992:557-629). When drafting such acts, the instinct is to list every activity that can conceivably be considered corrupt, and to avoid deliberate misinterpretation, as people are creative in finding ways to enrich themselves or their friends and family at the public's expense (World Bank, 2001:1).

According to Messick and Kleinfeld (2002:2), bright-line rules are easy to understand, simple to apply, and demand little or no judgment in determining their applicability. This statement is supported by Kaplow (1992:557-629) who states that such laws are contrasted with those which contain standards that are open to interpretation by enforcement agencies. The World Bank (2001:1-2) is also against broadly drawn provisions that set out a general standard such as the provision found in the laws of several nations making the abuse of public office for private gain, a crime.

Sanctions are centred on legislation that criminalises corruption (USAID, 1999:11). The aim of imposing stiff penalties is to make corruption a high-risk activity. Adequate anticorruption legislation should, apart from the normal bribery offences, create two unique offences: 
i. An offence for any civil servant to accept gifts, loans, discounts and passage, even if there are no related corrupt dealings, unless specific permission is given.

ii. An offence for any civil servant to be in possession of assets disproportionate to his/her official income; or living above his or her means (Man-wai, 2006:200).

The World Bank Group (2007:1) provides the following considerations that should be taken into account when creating anti-corruption laws:

i. The laws should match the enforcement capacity of the country's institutions. Since the level of integrity and capacity will be rather low in most countries where corruption is rampant, a law should be easy to understand and unequivocal in its applicability.

ii. Bright-line rules should be introduced: they are easy to understand and apply but come at the cost of reduced flexibility. Examples include a ban on the hiring of relatives or friends regardless of qualification and a ban on receiving any gift in excess of a small set value or a mandatory declaration of assets.

Having reviewed anti-corruption legislation in 21 countries, (Australia, Bangladesh, Cambodia, the Cook Islands, Fiji Islands, Hong Kong, China, India, Indonesia, Japan, the Republic of Kazakhstan, the Republic of Korea, the Kyrgyz Republic, Malaysia, Mongolia, Nepal, Pakistan, Papua New Guinea, the Philippines, Samoa, Singapore and Vanuatu), Chêne (2010:7) concludes that good practice examples of anti-corruption laws have been developed in Singapore, Hong Kong and, to some extent, in Malaysia.

Chêne (2010:7) identifies the following highlights about each country's legislation: Singapore's Prevention of Corruption Act (PCA) was enacted in 1960. The law explicitly defines corruption in terms of various forms of gratification and combines extensive prevention measures with severe sanctions and penalties. Hong Kong's Prevention of Bribery Ordinance 1970 (POBO) is a comprehensive piece of legislation that covers all types of bribery, both in the public and the private sectors, and Malaysia's Anti-Corruption Act 1997 provides for offences and penalties for private and public sector corruption, including active and passive bribery, attempted corruption and abuse of office, corruption through agents and intermediaries, corruption in public procurement and electoral corruption.

\section{State of anti-corruption legislation in South Africa}

The Department of Public Service and Administration and United Nations Office on Drugs and Crime (2003), Godi (2007), the Gauteng Anti-Corruption Strategic Framework (2009), Chêne, (2010) and Woods (2011) all commend South Africa for having a relatively sophisticated and comprehensive legal framework which deals with corruption, transparency in procurement, and financial management. However, the above authors also identify flaws in these laws when assessing their effectiveness, while several provide measures of how to mitigate these failures.

According to the Department of Public Service and Administration and United Nations Office on Drugs and Crime (2003:6), South Africa has unique legislation which empowers the general public to require information from the public sector (and to a lesser extent from the private sector) and to challenge administrative decisions. The Department of Public Service and Administration and United Nations Office on Drugs and Crime (2003:6) further expounds the fact that these laws greatly enhance transparency and contribute to clean 
government and provide state-of-the-art protection to whistle-blowers in a workplace. The Gauteng Anti-Corruption Strategic Framework (2009:8) argues that the elements of an effective anti-corruption framework exist in Gauteng.

The existing South African anti-corruption legislative framework is stable (DPSA, 2002:12). However, it is fragmented: there are capacity constraints in complying with it. It has proven to be ineffective: since the common law crime of bribery was repealed by this Act, prosecution of bribery cases has been insignificant. There are serious weaknesses and shortcomings in the capacity and will of public sector bodies to implement and to comply with the laws and there are overlapping mandates which affect the law enforcement agencies and the constitutionally created bodies (Department of Public Service and Administration and United Nations Office on Drugs and Crime, 2003:6).

According to Godi (2007:6), the public sector has uneven capacity to enforce and comply with the legislation, the courts are overloaded and struggle to retain experienced prosecutors, and the legislative mandates of some law enforcement and other agencies overlap. These laws do not function optimally and are not effectively adhered to: South Africa continues to rank amongst the highest in terms of levels of corruption and perceptions of corruption and there are inefficiencies within and between institutions with anti-corruption mandates, a lack of effective follow-up on complaints of corruption, inefficient application of disciplinary systems, underdeveloped management capacity in some areas and societal attitudes which weaken anti-corruption efforts (Gauteng Provincial Government, 2009:8).

Regarding the effectiveness of this law-directed anti-corruption approach, every indication has been that corruption, particularly in the public sector, continues to escalate and has now reached the point where South Africa is widely perceived as having one of the highest levels of public sector corruption in the world (Woods, 2011:1). Woods (2011:5) attributes this failure to poor management which results in weak application of laws and regulations, and subsequently deteriorating application of internal systems which, in turn, leads to opportunities for corruption. It has been established that effective implementation and enforcement of legislation are critical steps in efforts to achieve their effectiveness (DPSA, 2002:13).

A literature review on anti-corruption legislation in South Africa has revealed that it has not been successful, highlighting additional acts that need to be regarded as offences by legislation itself. The results of a recent empirical survey (which follow) suggest that the primary problem is inadequate enforcement of legislation.

In the following section, the role of anti-corruption agencies in combating corruption in South Africa is discussed.

\section{Role of ant-corruption agencies}

Since fighting corruption has become a key priority for a number of countries, initiatives have been taken towards achieving this goal. Such initiatives have multiplied through the inauguration of specific anti-corruption institutions or through watchdog organisations and anti-corruption legislation. The agencies and laws are required to monitor public ethics and to achieve levels of transparency, especially with regard to public sector decision-making.

Doig, Williams and Ashour (2012:4) define anti-corruption agencies as legal entities, permanent institutions in their own right, with full-time staff with executive responsibilities 
and not just advisory ones, related to at least one of three functions, namely: 'prevention', 'awareness' and 'law enforcement'. Johnsøn, Hechler, De Sousa, and Mathisen (2011:4) state that anti-corruption agencies (ACAs) are never given an easy or a well-defined task. De Sousa (2009:11) claims that ACAs may be set up in an attempt to upgrade a country's ethics infrastructure, respond to corruption scandals, or fulfil international treaty requirements.

ACAs are expected to: combat corruption in an independent, knowledge-based manner by developing a specialised repressive, preventive and educational/research capacity; secondly, overcome the inadequacy of traditional law enforcement structures and processes and assume a leading role in implementing national anti-corruption strategies; and thirdly, re-assure public opinion of the government's commitment to fight corruption (De Sousa, 2009:16).

Countries worldwide have embarked on various anti-corruption initiatives. Del Mar Landette (2002:3) writes that strategies to combat corruption are often led by independent anticorruption agencies created specifically to spearhead the fight. Specialised and independent anti-corruption agencies present the advantage of being exclusively devoted to fighting corruption (Transparency International, 2000:41). Heilbrunn (2004), Stapenhurst and Langseth (1997), Pope and Vogl (2000), Del Mar Landette (2002), Man-wai (2006), Jennett and Hodess (2007), Lincoln (2000), Camerer (1999) and Boone (2002) provide a compendium of features of effective anti-corruption agencies (ACAs). In addition, Stapenhurst and Langseth (1997) and Heilbrunn (2004) provide reasons why ACAs fail, also pointing in the same direction as to what an anti-corruption agency ought to be. It can be deduced that anti-corruption agencies have been an integral part of these initiatives.

\section{Features of effective anti-corruption agencies}

Camerer (1999:2), Heilbrunn (2004:18), and Stapenhurst and Langseth (1997:324-325) identified the following characteristics of ACAs: political backing, adequately resources, educational, independence and integrity. While De Sousa (2009:12) argues that there is no standardised model of what an ACA should look like, the National Planning Commission (2011:448) asserts that other than sufficient monetary resources, a number of important requirements that can be identified for an anti-corruption agency to function effectively include sufficient staff and resources with specific knowledge and skills, special legislative powers, high level information-sharing and co-ordination and operational independence.

Pope and Vogl (2000:6) and De Sousa (2009:12) identify criteria to be met by a particular agency in order to be classified as an ACA as being distinct from other enforcement agencies with competencies to combat corruption. National anti-corruption agencies should not be run by hand-picked supporters of politicians in power as such leaders could be deployed to intimidate political opponents (Pope and Vogl, 2000:8). There must be durability: they cannot have an occasional or perennial existence. Such agencies must also have the powers to centralise information, including its collection, storage, processing and diffusion - in other words, an information hub (Pope and Vogl, 2000:8). ACAs should also allow for articulation of initiatives undertaken by other control actors. Here the role of research and membership of and participation in international forums and networks are significant. Furthermore, ACAs should be characterised by the rule of law: there have to be checks and balances in place and there needs to be accountability to the sovereign authority. Finally, it is essential that their existence is known by and accessible to the public at large (De Sousa, 2009:12). 
According to Doig et al. (2012:7), an anti-corruption agency offers many advantages. Firstly, it sends a signal that the government takes anti-corruption efforts seriously. Secondly, a higher degree of specialisation and expertise can be achieved and a higher degree of autonomy can be established to insulate the institution against undue influences. The institution responsible for undertaking investigations will be separate from the agencies and the departments.

A completely new institution will enjoy a 'fresh start', free from corruption and other problems that may be present in existing institutions. In addition, it has greater public credibility and it can be afforded better security protection. An ACA will have greater political, legal and public accountability and there will be faster action against corruption. Furthermore, it will have greater political, legal and public accountability and there will be more clarity in the assessment of its progress, successes and failures. Task-specific resources will be used and officials will not be subject to the competing priorities of general law enforcement, audit and similar agencies. Finally, it incorporates an additional safeguard against corruption in that it will be in a position to monitor the conventional law enforcement agencies.

In the section that follows, the research methodology and design, the sample population and the interpretation of the findings are presented.

\section{The country's progress in the fight against corruption}

Besides pieces of legislation that have been passed and anti-corruption agencies that have been established to support the government's fight against corruption the following significant strides have been made:

i. Reformed management practices, including appointment and disciplinary procedures;

ii. Institution of financial disclosure requirements and performance systems for managers in the public service;

iii. Establishment of a new, fair and transparent supply chain management system to prevent corruption in procurement;

iv. Introduction of a Public Service National Anti-Corruption Hotline System; and

v. Institution of stringent financial management, risk management and fraud prevention requirements for public bodies.

A National Anti-Corruption Strategy was also formulated. As part of its implementation, in September 2003 the Cabinet decided to require all public service departments and entities to have a minimum level of anti-corruption capacity (Department of Public Service and Administration, 2006:7). In 2006, Guidelines for Implementing the Minimum AntiCorruption Capacity Requirement in Departments and Organisational Components in the Public Service were developed.

Notwithstanding all the above-mentioned measures, according to the National Planning Commission (2011:401), evidence gathered by the Commission indicates that South Africa suffers from high levels of corruption that undermine the rule of law and hinder the state's ability to effect development and socio-economic transformation. Research from the Transparency International's Corruption Perception Index indicates that South Africa has fallen from a respectable 34th place in world rankings in 2000, to 64th place in 2011 (Corporate Governance Framework Research Institute, 2012:42). Cronin (2012:1), who 
echoed the same sentiments, states that the challenges of corruption have escalated significantly in South Africa over the past decade; threatening democratic achievements, undermining the capacity of the state to advance socio-economic transformation, and eroding the solidarity culture that once underpinned the broad-based anti-apartheid struggle.

The National Planning Commission (2011:401) refers to it as the twin challenges of corruption and lack of accountability in our society which require a resilient system consisting of political will, sound institutions, a solid legal foundation and an active citizenry

that is empowered to hold public officials accountable. Criticising the enactment of the "Secrecy Act" in her Nelson Mandela Annual Lecture, Mary Robinson emphasised the lack of transparency and accountability that is becoming a problem in South Africa (Robinson, 2012:2-3).

\section{Empirical research}

A synopsis of the empirical survey of a comparative analysis of the effectiveness of the anticorruption legislation and anti-corruption agencies in the Eastern Cape and Northern Cape Provinces conducted by Majila (2012) is provided in the paragraphs that follow.

\section{Research instrument}

The research conducted by Majila (2012) employed a self-administered structured questionnaire designed in the form of a Likert scale. Through quantitative research the connection between empirical observation and mathematical expression of quantitative relationships was provided. One of its most common disciplines is the use of statistics to process and explain data and summarise the findings.

With regard to the above, the units of study in this empirical research consisted of the following:

The participants were comprised of selected officials from two provincial departments located in the Eastern Cape and Northern Cape. The total sample size was 108. The population of 100 officials and eight selected senior managers was targeted. A response rate of eighty-four per cent (84\%) was achieved. The research findings are based on 79 completed questionnaires. The responses by the participants to the various questions are presented descriptively.

\section{Ethical considerations}

A social researcher has to deal with a number of ethical obligations when undertaking research. Permission to conduct the study was obtained from the relevant provincial heads of departments in the Eastern Cape and Northern Cape Provinces. Ethical clearance was sought from the Human Research Ethics Committee at the Nelson Mandela Metropolitan University. All the participants who formed part of the sample for the empirical component of the research were informed of their rights. Each participant was required to sign the informed consent form indicating his or her voluntary willingness to participate in the empirical survey. 


\section{Data processing}

A statistical package was employed to process the collected data and to generate the various statistical results which emerged from the quantitative study. The relative values pertaining to the set statements that emerged from the survey were transferred in codified form to a computer database.

\section{Interpretation of research findings}

The following responses were recorded in response to several statements highlighted in bold print.

\section{Empirical survey resultsmpirical survey results}

\section{STATEMENT}

1. The province enforces anti-corruption

legislation.

2. Officials are convicted in terms of anticorruption legislation.

3. Whistle-blowers are protected in terms of anti-corruption

legislation.

4. Most prevalent cases of grand corruption are found where public officials in high positions, in the process of making decisions of significant financial value, routinely demand bribes or kickbacks to ensure that tenders or contracts are awarded to specific contractors.

5. Anti-corruption agencies in the province are financially adequately resourced.

6. Anti-corruption agencies independent of the party in power

7. Anti-corruption agencies are likely to

\section{PROVINCE FREQUENCY}

Strongly Disagree Neutral Agree Strongly disagree

Eastern Cape $\quad 30.5$

$$
30.5
$$

Northern Cape $\quad 30$

35 
discharge their duties without fear or favour.

8. Anti-corruption agencies have political backing at the highest levels of the provincial government.

9. Heads of anticorruption agencies are hired on merit.

10. Members of the public are free to complain to anti-corruption agencies without fear of recrimination.

11. Anti-corruption agency employees are adequately trained.

12. Anti-corruption agency employees dealing with sensitive cases are subject to random integrity tests.

13. Anti-corruption agencies accountable are Parliament.
Northern Cape 19

Eastern Cape $\quad 31$

Northern Cape 21

Eastern Cape 22

Northern Cape 23

Eastern Cape $\quad 28$

Northern Cape

23

Eastern Cape

25

Northern Cape 23

Eastern Cape

19

Northern Cape

21

Eastern Cape

22

to Northern Cape

21
30

50

28

44

28

47

\section{0}

44

26

28

28

36

23
9

26

16

3

8

8

16

$\begin{array}{lll}11 & 8\end{array}$

A total of 70 per cent of the Eastern Cape respondents and 65 per cent of the Northern Cape respondents did not support the statement that the province enforces anti-corruption legislation. Although at varying percentages, very few respondents supported the statement: the Eastern Cape responded at 10 per cent and those in the Northern Cape at 28 per cent. These results indicate that enforcement of anti-corruption legislation is poor. The Public Sector Integrity Management Framework (2006:5) explains that the ineffectiveness of the Protected Disclosure Act, 2000 has resulted in a lack of confidence in whistle-blowing against unethical conduct and corruption. This requires that hurdles that hinder the implementation of this Act are addressed.

In both the Eastern Cape and the Northern Cape large numbers of the respondents did not support the statement that officials are successfully convicted in terms of anti-corruption legislation: in the Eastern Cape 80 per cent held this view, as did 51 per cent of the respondents in the Northern Cape. Of the Eastern Cape respondents, 12 per cent agreed with the statement as did 42 per cent of the respondents from the Northern Cape, while eight per cent from the Eastern Cape and seven per cent from the Northern Cape remained undecided. Section 26 of the Prevention and Combating of Corrupt Activities Act 2004 provides for the conviction of those involved in corruption. However, the results indicate that officials are not convicted in terms of anti-corruption legislation.

Only six per cent of the Eastern Cape respondents and 23 per cent of the Northern Cape supported the statement that whistle-blowers are protected in terms of anti-corruption 
legislation. Impartial responses came from 41 per cent of the Eastern Cape respondents and 23 per cent from the Northern Cape; and the majority of both provinces' respondents, the Eastern Cape at 59 per cent and the Northern Cape at 54 per cent, responded negatively. Section 3 of the Protected Disclosures Act prohibits subjecting any employee to any occupational detriment by his or her employer on account, or partly on account of having made a protected disclosure. However, the responses show that employees do not believe that whistle-blower protection is provided in terms of this Act.

Of the Eastern Cape respondents, 81 per cent and 88 per cent of the Northern Cape respondents identified with the statement that most cases of grand corruption are prevalent where kickbacks are paid to ensure that tenders or contracts are awarded to specific contractors. A small percentage discounted the statement, namely 11 per cent from the Eastern Cape and 7 per cent from the Northern Cape. Impartial respondents from the Eastern Cape amounted to 8 per cent and from the Northern Cape, 5 per cent. Concerning the conviction of corruption offenders, Section 28 of the Prevention and Combating of Corrupt Activities Act provides that enterprises that are involved in corrupt offences be endorsed on the Register for Tender Defaulters. This register serves to name and shame those convicted of tender irregularities. Despite this Act and its provisions, the results indicate that kickbacks are paid to secure tenders and contracts. This conclusion is justified because the Register for Tender Defaulters does not have any names listed. It has been blank since its establishment.

The statement that anti-corruption agencies in the province are adequately financially resourced was discounted by 55 per cent of the respondents from the Eastern Cape and 49 per cent of the respondents from the Northern Cape. Neutral responses were noted from 33 per cent of the Eastern Cape respondents and 28 per cent from the Northern Cape whilst 12 per cent of the Eastern Cape respondents and 23 per cent from the Northern Cape supported the statement. Chapter 14 of the 2030 National Development Plan (2011:447) states that fighting corruption requires an anti-corruption system that is well-resourced. However, the responses show that anti-corruption agencies in the provinces are financially inadequately resourced. This is detrimental to the success of anti-corruption initiatives.

The statement that anti-corruption agencies are independent of the party in power was discounted by both provinces: the Eastern Cape respondents by 72 per cent and the Northern Cape by 58 per cent. Support for the statement came from 17 per cent of the Eastern Cape respondents and 33 per cent from the Northern Cape, with 11 per cent of the Eastern Cape respondents and 7 per cent from the Northern Cape remaining neutral. Anti-corruption agencies in South Africa are accountable to the Executive. According to Chapter 14 of the 2030 National Development Plan (2011:448), this compromises the independence of anticorruption agencies, since this may leave them vulnerable to political pressure and interference. The responses could imply that anti-corruption agencies are dependent on the party in power.

Regarding the statement that anti-corruption agencies are likely to discharge their duties without fear or favour, 72 per cent of the Eastern Cape responses and 49 per cent from the Northern Cape disagreed, while 17 per cent of the Eastern Cape responses and 42 per cent from the Northern Cape agreed with the statement. Impartial responses were recorded from 11 per cent of the Eastern Cape and 9 per cent from the Northern Cape. The results indicate that anti-corruption agencies are unlikely to discharge their duties without fear or favour. As 
shown by responses to statement B10 above, anti-corruption agencies depend on the party in power. They are, therefore, unable to make credible judgments.

The statement that anti-corruption agencies have political backing at the highest levels of the provincial government was refuted by 81 per cent of the Eastern Cape responses and 49 per cent from the Northern Cape, with 11 per cent of the Eastern Cape responses and 44 per cent from the Northern Cape supporting it and 8 per cent of the Eastern Cape responses and 7 per cent from the Northern Cape remaining neutral. To tackle corruption, there must be political will and support for anti-corruption agencies (Chapter 14 of the 2030 National Development Plan, 2011:449). However, the results indicate that anti-corruption agencies do not receive the intended support. Chapter 14 of the 2030 National Development Plan (2011:449) describes political will as not referring merely to public statements of support, but as also providing sufficient resources and taking action against corrupt officials.

A response rate of 75 per cent from the Eastern Cape and 53 per cent from the Northern Cape refuted the statement that members of the public are free to complain to anticorruption agencies without fear of recrimination. Support for the statement came from 14 per cent of the respondents from the Eastern Cape and 40 per cent from the Northern Cape whilst 11 per cent of the responses from the Eastern Cape and 7 per cent from the Northern Cape remained neutral. A large percentage of responses disagreeing with the statement indicates that citizens are afraid to stand up against corruption. This means that there are stumbling blocks that impede the progress in the fight against corruption. This therefore calls for immediate action by the government in order to emphasise the importance of public participation in combating corruption and promoting integrity. Principles of participatory democracy as enshrined in Sections 59(1) (a), 72(1) (a) and 118(1) (a) of the Constitution should be adhered to.

The majority of the respondents discounted the statement that anti-corruption agency employees are adequately trained, that is, 69 per cent from the Eastern Cape and 49 per cent from the Northern Cape, while. 14 per cent of the respondents from the Eastern Cape and 37 per cent from the Northern Cape supported the statement. Impartial responses came from 17 per cent of the respondents from the Eastern Cape and 14 per cent from the Northern Cape. These results indicate that anti-corruption agency employees lack adequate training. However, according to Jennett and Hodess (2007:2), expertise and continuous training are essential if the highest professional standard of an ACA is to be maintained. This means that equipping anti-corruption agency personnel with the necessary skills is crucial.

The statement that anti-corruption agency employees dealing with sensitive cases are subject to random integrity tests was discounted by 47 per cent of the Eastern Cape respondents and 49 per cent of the Northern Cape respondents. Support for the statement came from 9 per cent of the respondents from the Eastern Cape and 32 per cent from the Northern Cape. 44 per cent of the responses from the Eastern Cape and 28 per cent from the Northern Cape remained neutral. A large percentage of the responses indicates that random integrity testing of anti-corruption agency employees is not performed. Judging by responses to statements B12 and B13, it is evident that the integrity of the agencies is not one of the sought-after characteristics. The fact that heads of these agencies are handpicked by corrupt politicians and are instructed not to investigate certain cases is indicative of dishonesty. The National Development Plan (2011:402) states that Vision 2030 promotes a zero tolerant South Africa for corruption where leaders hold themselves to high ethical standards and act with integrity. 
The respondents (the Eastern Cape 58 per cent and the Northern Cape 44 per cent) discounted the statement that anti-corruption agencies are accountable to Parliament. 6 per cent of the respondents from the Eastern Cape and 28 per cent of those from the Northern Cape supported the statement. Impartial responses of 36 per cent from the Eastern Cape and 28 per cent from the Northern Cape were recorded. The above responses imply that anticorruption agencies are not accountable to Parliament. This is true. However, anti-corruption agencies in South Africa are accountable to the Executive instead of to Parliament. This means that government accountability needs to be strengthened.

It can be inferred from the above responses that anti-corruption agencies are not accountable to Parliament. In South Africa, anti-corruption agencies are accountable to the Executive instead of to Parliament.

\section{Summary: findings}

It is evident that there is systematic use of the public office for private benefit. This results in inferior quality or the unavailability of public goods and services. This is facilitated by networks and alliances that use the political system and state resources to sustain unethical behaviour. The survey established that, in addition to implementation lacunae, anticorruption legislation enforcement is being politicised. When this happens, whether laws should be enforced in an appropriate manner ultimately depends on the will and determination of political leaders. Political power is used to shield corrupt activities of family, friends, or political supporters, or both. It is concluded that existing anti-corruption agencies are unable to devote their efforts in their entirety to performing the necessary functions to fight corruption.

It was also revealed that anti-corruption agencies are functionally and technically incapacitated. Anti-corruption agencies appear to lack credibility, independence and accountability. The empirical component of this article revealed that employees of anticorruption agencies are inadequately trained and inadequately remunerated. The survey further revealed that the rule of law is not applied as stringently in South Africa as it should be. It can be inferred that a lack of fear of any criminal prosecution is a further reason why anti-corruption agencies are open to manipulation.

\section{Recommendations}

It is essential that the right of access to information enshrined in the 1996 Constitution is upheld for all. Espousing this right augments democratic principles of openness, transparency and accountability. South Africa has passed the freedom of information legislation, for example, the Promotion of Access to Information Act 2 of 2000 and the Promotion of Administrative Justice Act 3 of 2000. The former sets out the procedure to obtain access to information held by the state while the latter ensures that decisions that affect the public are taken in a way that is procedurally fair. These two Acts are meant to promote transparency and prevent the government from operating in secret.

Lack of access to information hinders the implementation of anti-corruption initiatives. The country should reverse the apparent culture of secrecy. When little or no information is released to the public, the scrutiny of government agencies becomes difficult. In order to 
enhance levels of trust between communities and the government, the public should be further mobilised against corrupt behaviour by public officials and politicians in all spheres of government.

While the researchers' acknowledge that monopoly of power is possibly linked to corruption of the political system, it is strongly suggested that, for the benefit of the country's survival, no political party should have exclusive control over power. Domination of South Africa's political environment by one political party for an extended period has led the current government to use its means to its own ends. The influence persists to ensure that antimonopoly measures are not undertaken or that, if they are undertaken, they are merely superficial, taken to strengthen and extend the ruling party's monopolistic position and to weaken legislation in order to entrench its philosophy. It has been revealed by the study that because excessive power has been vested in the executive wing of government, it is being abused. Where systemic corruption exists, the longer the same political party remains in power, the more the processes are influenced on its behalf. The influence persists to ensure that anti-monopolistic measures are not undertaken or, if they are undertaken, they are merely superficial, taken to strengthen and extend the ruling party's monopolistic position and to weaken legislation in order to entrench its philosophy.

Discretion is a vital tool in management. It is meant to enable decision-makers to make decisions which represent a responsible choice. However, too much discretion exacerbates corruption. In order to promote transparency and effective control systems, excessive discretionary powers should be limited.

Merit-based appointment of government employees is the basis for the public service. The Public Service Commission developed a Toolkit on Recruitment and Selection in the public service. The Toolkit is meant to provide guidance in selecting the most competent persons available, within the parameters of the Affirmative Action and Employment Equity legislation. It encourages merit-based recruitment for senior civil service positions. Compliance with the Public Service Commission Toolkit on Recruitment and Selection in the public service is recommended, together with all other prescripts in the public service. This should be stringently monitored and controlled.

The prescripts of the legislation must be written in such a way that it is easy to understand and apply. The vulnerability of legislation to deliberate misinterpretation should be avoided. Enforceability of anti-corruption legislation will enhance the protection of whistle-blowers from victimisation, encourage communities to blow the whistle when necessary, and facilitate successful investigations.

It is recommended that the implementation of anti-corruption legislation be depoliticised.

Furthermore, anti-corruption legislation should also be amended. This should be undertaken through broadening the scope of protection in a whistle-blower law and the range of bodies to which a protected disclosure may be made. An organisation that is tasked with providing advice and promoting public awareness as well as a public entity dedicated to monitoring whistle-blowing should be established. Anti-corruption laws should protect whistle-blowers from being terrorised and discredited. It is recommended that South Africa should establish a centralised anti-corruption agency tasked with deterrence from, prevention of, education about and prosecution of corruption cases. 


\section{Conclusion}

This article reviewed anti-corruption legislation and anti-corruption agencies in dealing effectively with corruption in the Eastern Cape and Northern Cape Provinces. The research undertaken identified factors affecting the effectiveness of anti-corruption legislation and agencies; compared and analysed the effectiveness of anti-corruption legislation and agencies in the two selected provinces and identified and analysed factors associated with compliance or non-compliance with the anti-corruption measures in these provinces.

\section{Bibiography}

Babbie, E. and Mouton, J. 2001. The practice of social research. Cape Town: Oxford University Press Southern Africa.

Bassey, E., Ndem, BN., Michael, B. and Awa, OC. 2012. Social capital, corruption and economic growth in Nigeria: A case study of some contracts awarded by Niger Delta Development Commission in Akwa Ibom and Cross River State. Journal of Economics and Sustainable Development, 3(11).

Camerer, L. 1999. Tackling the multi-headed dragon: Evaluating prospects for a single anticorruption agency in South Africa. Paper presented at the 9th International AntiCorruption Conference. Johannesburg.

Carr, I. and Outhwaite, O. 2008. Surveying corruption in international business. Manchester Journal of International Economic Law, 5(2).

Charron, N. 2008. Mapping and measuring the impact of anti-corruption agencies: A new dataset for 18 countries. Prepared for the New Public Management and the Quality of Government Conference, Götenborg: Sweden.

Chêne, M. 2010. International good practice in anti-corruption legislation. Transparency International.

Chêne, M. and Hodess, R. 2010. International good practice in anti-corruption legislation. Transparency International.

Corporate Governance Framework Research Institute. 2012. Fighting corruption to achieve the Millennium Development Goals (MDGS). Johannesburg.

Cronin, J. 2013. We've been structured to be looted (A Senior Public Sector Manager). Some reflections on the systemic underpinnings of corruption in contemporary South Africa. Johannesburg: University of the Witwatersrand.

Cooper, DR. and Schindler, PS. 2001. Business research methods. $7^{\text {th }}$ edn. Boston: McGraw Hill.

Danon, M. 2010. Contemporary economic research of corruption. Óbuda University Keleti Károly, Faculty of Business and Management. Tavaszmezı.

Del Mar Landette, M. 2002. Combating corruption: What the Ecuadorian Anti-Corruption Agency can learn from international good practice. University of Birmingham School of Public Policy International Development Department. 
Department of Public Service and Administration. 2011. The public sector integrity management framework. Pretoria.

Department of Public Service and Administration. 2006. Minimum anti-corruption capacity requirement. Pretoria.

Department of Public Service and Administration and United Nations Office on Drugs and Crime. Country corruption assessment report, 2003. Pretoria.

De Sousa, L. 2009. Anti-corruption agencies: Between empowerment and irrelevance. Springer Science.

De Speville, B. 2008. Empowering anti-corruption agencies: Defying institutional failure and strengthening preventive and repressive capacities. Lisbon: Instituto Universitário De Lisboa.

Doig, A., Williams, R. and Ashour, AS. 2012. Anti-corruption agencies, reflections on international standards and experiences and considerations for Arab countries. [Online] Available from: http://www.Magnet.Undp.Org. [Retrieved on 30 November 2012].

Financial disclosure framework.[Online] Available at http://www.psc.gov.za/documents/pubs/newsletter/2007/2008-h.asp. [Retrieved on 30 November 2012].

Gauteng Provincial Government. 2009. Anti-corruption strategic framework. Johannesburg.

Gebeye, BA. 2012. Corruption and human rights: Exploring the relationships. Free Legal Aid Center, School of Law, Jigjiga University: Ethiopia.

Godi, T. 2007. Fighting corruption and safeguarding integrity. Global Forum V, Sandton, South Africa.

Hean, SK. 2010. Corruption control in Singapore. Resource Material Series No. 80.

Heilbrunn, JR. 2004. Anti-corruption commissions: Panacea or real medicine to fight corruption? World Bank Institute: Washington DC.

Hin, KT. 2011. Corruption control in Singapore. United Nations Asia and Far East Institute for the Prevention of Crime and the Treatment of Offenders (UNAFEI). Resource Material Series No. 83.

Hussmann, K., Tisne, M. and Mathisen, H. 2009. State building: Anti-corruption with a state building lens. OECD. Switzerland.

Institute for Security Studies. 2003. Scorpions have been stung. Umqolecuphandle $S A$ Corruption Briefing, 005, 26 June 2003.

International Bar Association. 2012. South Africa country brief: Anti-corruption strategy for illegal profession. Durban.

Jackson, P., Muzondidya, J., Naidoo., Ndletyana, M. and Sithole, MP. 2009. South African governance in review: Anti-corruption, local government, traditional leadership. Cape Town: HSRC Press.

Jennett, V. and Hodess, R. 2007. The criteria for selecting appointees for anti-corruption agencies. Transparency International. Geneva. 
Johnsøn, J., Hechler, H., De Sousa, L. and Mathisen, H. 2011. How to monitor and evaluate anti-corruption agencies: Guidelines for agencies, donors, and evaluators. UNDP Anticorruption Resource Centre. Singapore.

Kaplow, L. 1992. Rules versus standards: An economic analysis. Duke Law Journal, 42 (3).

Kolstad, I., Verena Fritz, V. and O'Neil, T. 2008. Corruption, anti-corruption efforts and aid: Do donors have the right approach? Advisory Board for Irish Aid: Ireland.

Lian, AS. 2008. Singapore experience - Dealing with governance and corruption corrupt practices. Investigation Bureau: Singapore - Lisbon.

Lincoln, YS. and Guba, EG. 1985. Naturalistic inquiry. Newbury Park, AC: Sage.

Majila, VT. 2011. A comparative analysis of anti-corruption legislation and anti-corruption agencies in the Eastern Cape and the Northern Cape Provinces: A governance perspective. Unpublished thesis for the Degree of Doctor of Philosophiae, Faculty of Arts, Nelson Mandela Metropolitan University, Port Elizabeth.

Man-wai, TK. 2006. Formulating an effective anti-corruption strategy - the experience of Hong Kong ICAC. United Nations Asia and Far East Institute for the Prevention of Crime and the Treatment of Offenders Resource Material Series.

Menipaz, E. and Menipaz, A. 2011. International business: Theory and practice. London: UK SAGE.

Messick, RE. and Kleinfeld, R. 2001. Writing an effective anti-corruption law. Public Sector, PREM Network, World Bank.

Mollah, AH. and Uddin, N. 2002. Combating corruption in Bangladesh: Some strategies.

Department of Public Administration, University of Rajasthan. Bangladesh.

National Planning Commission. 2011. National Development Plan. Pretoria: Government Printer.

Nekabari, JN. and Oni, AJ. 2012. The institutional approach to anti-graft crusade: The case of independent corrupt practices commission in Nigeria. African Journal of Social Sciences, 2 (1).

National Planning Commission. 2011. National Development Plan. Pretoria.

OECD 2013. Specialised anti-corruption institutions: Review of models, $2^{\text {nd }}$ edn. OECD Publishing. Singapore.

Persson, AP., Rothstein, B. and Teorell, J. 2012. Why anticorruption reforms fail-systemic corruption as a collective action problem. New York: Wiley Periodicals.

Pope, J. 2000. Confronting corruption: The elements of a national integrity system. Transparency International: Berlin, Germany.

Pope, J. and Vog1, F. 2000. Making anti-corruption agencies more effective. Finance $\xi^{\circ}$ Development a Quarterly Magazine of the IMF, 37 (2).

Reno, W. 2008. Anti-corruption efforts in Liberia: Are they aimed at the right targets? International Peacekeeping. London: Routledge. 
Robinson, M. 2012. Freedom, truth, democracy: Citizenship and common purpose. Nelson Mandela Centre of Memory, Houghton.

Saryazdi, AH. 2012. Main elements of an effective anti-corruption strategy. Journal of American Science, 8(12).

South Africa. The Protected Disclosures Act 26 of 2000. Pretoria: Government Printer.

South Africa. The Prevention and Combating of Corrupt Activities Act 12 of 2004. Pretoria: Government Printer.

Stapenhurst, F. and Langseth, P. 1997. The role of the public administration in fighting corruption. Economic Development Institute. International Journal of Public Sector Management, 10 (5).

Transparency International. 2011. [Online] Available at: http://www.transparency.org/country. [Retrieved on 17 February 2011].

The Presidency. 2010. Second Report on the Implementation of South Africa's APRM Programme of Action. Lusaka.

UNDP. 2009. Methodology for assessing the capacities of anti-corruption agencies to perform preventive functions. UNDP Bratislava Regional Centre.

USAID. 1999. Handbook on fighting corruption. Center for Democracy and Governance Bureau for Global Programs, Field Support, and Research U.S. Agency for International Development Washington, D.C

US Department of State. 2012. Investment climate statement - South Africa. Bureau of Economic and Business Affairs: United States.

Vian, T. 2008. Review of corruption in the health sector: theory, methods and interventions. Oxford: Oxford University Press.

Woods, G. 2011. Anti-corruption legislation - a failed response to procurement corruption. Paper presented to the Public Procurement Regulation in Africa Conference, Stellenbosch, South Africa.

World Bank. 2001. Writing an effective anti-corruption law. Public Sector Preliminary notes No.58.

World Bank Group. 2007. Institutional restraints on power. The World Bank: Washington, DC.

World Economic Forum. 2009. Raising our game: Next steps for business, government and civil society to fight corruption. Global Agenda Council on Corruption, Cologne/Geneva, Switzerland.

Yaru, MA. 2010. Economic perspective of corruption in public sector: A theoretical explanation and lessons for Nigeria. Ilorin Journal of Business and Social Sciences (IJBSS) 13(2).

Zimbardo, P. and Ebbeson, EB. 1969. Influencing attitudes and changing behaviour. Massachusetts: Addison-Wesley. 